\title{
The Monetary Policy in Indonesia: in the Perspective of Islamic Economics
}

\author{
Iwan Wisandani ${ }^{1^{*}}$ \\ Sri Iswati ${ }^{2}$ \\ Rifki Ismal ${ }^{3}$ \\ 1/slamic Economic Studies Program, Faculty of Islamic Studies, \\ Siliwangi University Tasikmalaya, West Java, Indonesia. \\ 2Faculty of Economic and Business, Accounting, Airlangga University, \\ Surabaya, East Java, Indonesia. \\ ${ }^{3}$ Central Bank of Indonesia, Jakarta, Indonesia. \\ *Corresponding Author, Email: iwanwisandani@unsil.ac.id
}

\begin{abstract}
:
The writing is based on my concern about the monetary policy in Indonesia which is not entirely by the Islamic teaching. Among all, the monetary policy doesn't pay attention to the real sector. It can be seen from the sectoral dichotomy between the real and monetary sectors whereas, in Islamic economics, monetary policy is only a representative of the real sector. The paper is a literary research with the approach of a comparative study between Islamic monetary policy and the monetary policy employed in Indonesia. The research result is a composition of a transmission model from the perspective of Islamic economics which is based on BI Return (sharing) by creating a diagram and then explaining some thoughts of Muslim and western economists such as Stiglitz to create a monetary policy which gets along with the real sector. The model is an observational result to the monetary condition in Indonesia which is then compared to Islamic monetary thought. This model will gain good result when all transmissions of monetary policy are applied effectively.
\end{abstract}

Keywords: Model, BI Return. Islamic Monetary Policy.

\section{A. INTRODUCTION}

In the conventional economy, interest is a very important variable as an instrument and target intermediation in its monetary policy to create stability, where supply and demand dominantly influence the amount of money circulating in the society. In fact, the efficacy of interest system in gaining the goal of the monetary policy is still a big question in the empirical world. Some research shows that the correlation between interest and the level of national savings and investment is still far away; unlike it is in the theory (Arietta, 1988:119). The same thing is found in the research result of Khatkhate (Khatkhate, 1988:135) about the influence of interest to some macro economic variables such as the growth level of real PDB, real financial asset, saving income ratio, investment income ratio, and rate of return on investment, in 64 developing countries along the period of 1971 1980. Therefore, the deletion of interest based instrument is a must. 
In addition, today's world economy is getting down. One of the reasons is the conventional monetary policy which so far employs the instrument of interest to influence the money supply is considered not effective. Stiglitz believes that it has to be changed into a policy based on the mechanism of credit supply and demand (real sector oriented). By so doing, the focus of new monetary economics theory is the arrangement of credit availability for the economic system (not the arrangement of interest or money supply). Therefore, it is expected to have a direct positive influence to the economic system.

\section{B. METHODS}

The method used in this research is literature study. The literature study in this study was conducted to study the definition of keywords, to deepen theories and concepts and to identify the variables related to the background and the research context. The literature study was obtained from previous research journals. The review method used in this literature study is the systematic literature review defined as a process for identifying, assessing and interpreting all available research results to answer specific research questions (Petticrew and Roberts, 2006).

Study method, style and some images inspired by Wahono (2015):

Figure 1: Systematic Literature Review

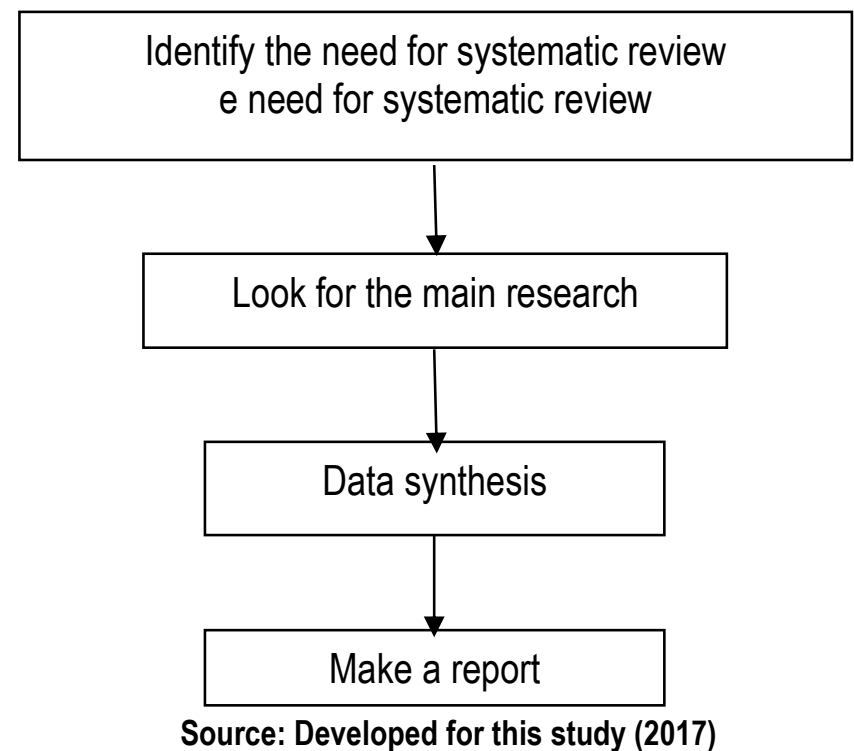

\section{RESULT AND DISCUSSIONS}

\section{The Monetary Policy in Indonesia}

\section{a. The theory of Monetary Policy}

A monetary policy is the process of organizing money supply of a particular country to achieve a certain goal; such as withholding the inflation or achieving the goal of more prosperous workers. Monetary policy can involve the setting of interest standard of loan, margin requirement, capitalization for banks or even acting as the last creditor or through an agreement with another organization or another government. Monetary policy basically aims at achieving internal equilibrium (high economic growth, price stability, and equitable development) and external equilibrium (the balance seen from the balance sheet) and achieving the aim of macro economy which is keeping the economic stability which can be measured by the availability of employment, the stability of price 
and the balanced international payment. When the stability of economic activities is disturbed, then monetary policy can be used for recovery (the acts of stability). The influence of monetary policy will first be felt by the sector of banking and next it will be transferred into the real sectors.

Monetary policy is an effort for controlling the condition of macro economy so that it can run as it is expected through the arrangement of money supply in an economic system. The effort is done so that prices and inflation will be stabilized and the balanced output can be reached. The experts of classical economy believe that monetary policy is more effective than the policy of fiscal. In its development, by the appearing of monetarists that are actually hold classical theories, the different opinion on neo-Keynesian is not more found along the curve of IS and LM.

The general frame that is commonly used in analyzing simultaneous interaction between supply and demand both in the money market and also in the goods market is the frame of IS-LM. This frame can show how monetary policy and fiscal are able to influence the level of income or output. To the central bank, which has the monetary authority, the policy chosen depends on the target, the actual condition of the economy, the capacity of policy and a consideration on the efficacy of the policy. This monetary policy is centrally determined by Bank Indonesia. Although in formulating its policy Bank Indonesia has considered regional aspect, yet the response from the agent and the effect of each region still tend to be different. It heavily depends on the empirical condition of each area.

Thought the above suggests that the stability of the target (in this case the interest rate) is an important factor to be observed, because he has a very close relationship with the ultimate goal of monetary policy is to be achieved, ie the inflation rate (Komaludin, 2009).

The following is the thought of Stiglitz on the Curve of General Equilibrium:

Figure 2: The Curve of General Equilibrium by Stiglitz

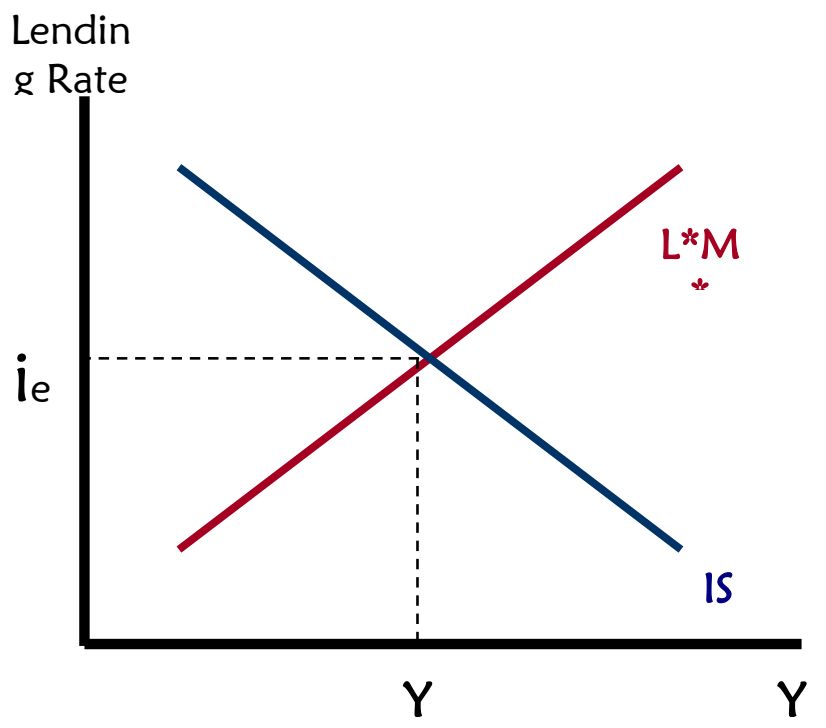

The Equilibrium of the Real Sectors (IS)

$Y=C+I+G+(X-M)$

$\mathrm{C}=\mathrm{Co}+\mathrm{b} Y d \quad \mathrm{Yd}=\mathrm{Y}-\mathrm{Tx}+\mathrm{Tr} \quad \mathrm{Tx}=\mathrm{tY}$

$I=10-g i$

$\mathrm{G}=\mathrm{Go}$

$N X=X-M$ 

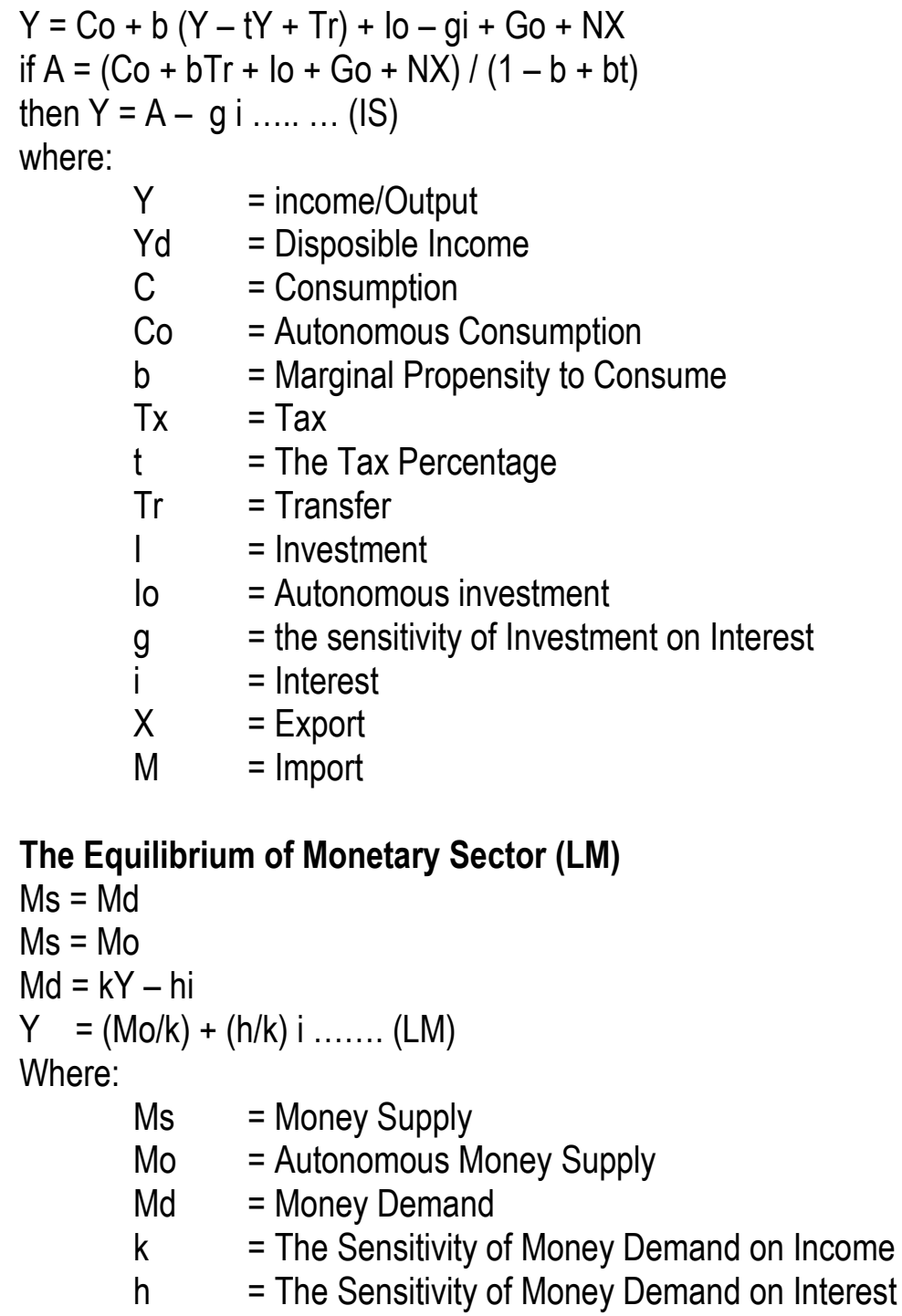

The concept of IS-LM is established because there is a belief that there is a market dichotomy where the markets of goods and service as genuine market is assumed to have 'a partner'. The market is called as money market, money market, capital, obligation, and derivative. The money market pays more attention to the dynamics of money supply and money demand. Nevertheless, the main point is the balance of money market, where the position of money demand is the same as the money supply, functioning interest as an indicator variable of balance or balance price.

The main focus that places interest as Price, "insisting" the real sectors to use interest as its Price when the balance between two of them was assumed to happen. Whereas as it is explained before that both of the sectors have different kinds of interest (as one of the variables). On the side of interest real sector, the variable tends to be the interest from loan because it is from the function of investment. Joseph E. Stiglitz and Bruce Greenwald try to correct this inconsistency by offering a new paradigm in viewing and defining general equilibrium (Stiglitz and Greenwald, 2003). Stiglitz and Greenwald offer a different focus in the sector of monetary, which is credit supply or the stream of loanable fund. So that the equilibrium Price is the credit rate. 


\section{b. The Monetary Policy in The Bank of Indonesia}

Bank Indonesia (BI, it used to be called as De Javasche Bank) is the central bank of the Republic of Indonesia. As the central bank, $\mathrm{BI}$ has one main purpose, which is achieving and keeping the stability of rupiah value. The stability of rupiah value has two aspects, which is the stability of currency to goods and service, as well as its stability to other countries' currency. To achieve the purpose, since 2005, Bank Indonesia has applied the frame of monetary policy with the inflation as its main target (Inflation Targeting Framework) by holding the system of free floating. The role of exchange value is very important in achieving price stability and financial system. Therefore, Bank Indonesia also runs the policy of exchange value to decrease the volatility of too high, instead of directing the exchange value to a certain level.

To achieve the purpose, $\mathrm{Bl}$ is supported by the three pillars which are its duties. These three duties are determining and implementing the monetary policy, arranging and keeping the payment system, and arranging and watching the banks in Indonesia. These three duties need to be integrated so that the stability of rupiah value can be achieved efficiently and effectively. BI is also the only foundation that has the authority of publishing money in Indonesia. In doing its duties and authorities, $\mathrm{Bl}$ is led by the board of Governor.

The monetary policy in Indonesia is an integral part of macro economic policy which is to achieve the prosperity of the society. This monetary policy is implemented by influencing money supply, so that it can press the inflation (the rising of prices). So, the only purpose is Inflation Targeting whereas the duty of Bank Indonesia is to achieve and maintain the value of rupiah (Act of BI No. 3 Year 2004).

The monetary policy in Indonesia, in this case is run by Bank Indonesia, uses interest as the monetary instrument, which is through the interest rate of Bank Indonesia Certificate and the interest rate of Loan Facility of Bank Indonesia can still be responded by the increase of the interest rate in the money market and the credit interest rate so that it decreases the number of economic liquidity and is expected to press the inflation. However, the decrease of monetary instrument which is interest rate does not guarantee the decrease of the interest rate in money market, not to mention the credit interest rate. Along with the more integrated money market, money owners have so many options to invest their money both in the country and abroad. Therefore, even though the monetary instrument, which is interest rate, decreases, the investors will remain looking for other high revenue by investing their money both in the country and abroad.

Bank Indonesia, on the side of monetary policy, has been very responsive with what happens today. However the problem appearing now is fundamental and not temporary which usually can be solved by Bank Indonesia alone. When economic recess happens, then monetary policy is almost impossible to be implemented. Therefore, Bank Indonesia has to make coordination with the government and the house of representative as the fiscal authorities. What is believed today is that the monetary policy is the main policy that can be used to control short and long term economy. In this case, there are two policies: first is the policy of expansive monetary which is done when there is high unemployment in the society. For this case, the government adds money supply in the society by lowering down the interest rate. The second is the policy of contractive monetary which is done when the country is having inflation. The government decreases the money supply by increasing the interest rate.

In its implementation, Bank Indonesia has the authority to implement the monetary policy by determining monetary targets (such as money supply or interest rate) with the main goal of keeping 
the inflation rate determined by the government. Operationally, the control over those monetary targets uses some instruments, such as the operation of open market in the money market both rupiah and also foreign currencies, the determination of bank discount, the determination of minimum reserve fund, and the arrangement of credit or finance. Bank Indonesia can also implement some ways of controlling the monetary matter by applying the principle of sharia.

\section{Monetary Policy in The Perspective of Islamic Econimics}

\section{a. A Glance of Islamic Economics Theory}

It has to be confessed that in a certain level (such as economic knowledge), that the system of Islamic economis is not as well established as that of capitalism in the format and the measuring tools. Even in the level of definition, there are so many variations from the experts. Let's take a look at the followings:

According to SM Hasanuz Zaman (1984), Islamic economics is the knowledge and application of injunction and rules of the sharia that prevent injustice in the acquisition and disposal of material resource in order to provide satisfaction to human beings and enable them to perform their obligations to Allah and the society.

According to M. Abdul Mannan (1986), Islamic economics is social science which studies the economics problems of people imbued with the values of Islam.

According to Khurshid Ahmad (1992), Islamic economics is the Muslim thinkers response to the economics challenges of their times. In this endeavor they were aided by the Quran and the Sunnah well as reason and experience.

So far, there is no theory or expert's point of view (according to the perspective of Islam) which arranges the balance of real sectors and monetary, except that an economic system has to rely on the real sectors as the locomotive of its movement, whereas the monetary sector is considered as only a supporter.

The concept of Islamic economics is different from that of the capitalist or the one which is usually reffered as conventional economics. The difference does not only lie on the principle of aqeeda (the core of the belief), but also covers the value standard, and methods applying it.

The concept of Islamic economic is based on the shareea that rules our life. It is believed that anything done by humans is included in the economic and developmental policies, and the economic activities of its society have to be bound with shareea. In solving economic problem and building economic concepts in Islam, Taqiyuddin an-Nabhaniin his monumental book, Al-Nizām Al-Iqtișādī fi Al-Islām states that basically the method used to solve the economic problems is the same as the method to solve other problems in people's life. It means that in every single thing that happens to human beings, the solution has to be the shareea. The only difference is the field or the object, not the rules (Karim, 2010).

\section{b. The Monetary Policy in the Classical Period of Islam}

Monetary policy is a monetary authority or the central bank in the form of monetary control to achieve the development of the expected economic activities. Basically, monetary policy is a policy to process money offer and demand, so that it can be condusive for the economic development. In 
the early era of Islam, there was a foundation, namely Bayt al-Māl which had the same duties as the central bank today. Bayt al-Māl was the Central Finance House which had many branches in all Islamic countries, where it ran almost all functions of today central bank, such as publishing currency and maintaining the stability of its value.

Bayt al-Māl is a concept of broad treasury, even there are some evidences showing that all belongings of muslims were parts of Bayt al-Māl, regardless their physical location. The concept of Bayt al-Māl bases on a basic belief that Allah, the All Mighty, is the absolute owner of this universe. Countries (caliphates) were established to conduct the teachings from Allah, including maintaining the prosperity and arranging the rights of the society on their belongings. In conducting this function, Baitul Maal was established and it was formed with three different institutions. They were (Mannan, 1986):

1. Bayt al-Māl al-Khāṣ;

2. Bayt al-Māl;

3. Bayt al-Māl al-Muslimīn.

Bayt al-Māl al-Khāș is a treasury institution of a country that has a special function which is managing governmental funds, such as the private expense of the caliphate, and some other special expenses. On the other hand Bayt al-Māl is like a bank in Islamic countries. The duties of this foundation are still very simple, but are very basic like they are in the modern economy, except in three things: (1) the publishing of currency, (2) the provision of finance, and (3) the supervision of interest rate. The function of publishing currency was not done because at that time muslim society used the currency published by another country which was dinar from Bizantium and dirham from Persia.

Bayt al-Mâl did not distribute the finance to the society either, even though at that time, trading was well established. Islamic society used to improve their enterprises by using the capital from another party, but the mechanism was not borrowing, but by giving capital (syirka). This kind of practice spread broadly in the muslim society in Madinah, but it was not done by Bayt al-Māl. The supervision of interest rate, as the modern central bank, was not done for sure because Islam does not allow interest.

Nevertheless, Bayt al-Māl al-Muslimin is a treasury foundation in a broad meaning, which was the treasurer of all muslim and people in general that has function of distributing the fund for public necessities such as road work, improving the life quality of the poor and some other necessities of people. So that the history has proven that the effort of improving people's prosperity was not only for muslim because in the era of Rasulullah and khulafaurrasyidin, the society was very heterogeous. All of them got guidance and prosperity from the government of Islam.

\section{c. Monetary Policy in the Era of Modern Islam}

In Islamic economics, monetary policy is only a representative of the real sector (Chowdury, 1997). The consequence is, the dichotomy of monetary sector is not relevant, because the monetary sector always correlates directly to the real sectors. The deletion of interest, on one hand, and the implementation of loss profit sharing on the other hand is a built in system which will connect these two sectors. Return on investment in the sector of monetary is the representative of Return on investment in the real sector. Based on this argument, it is believed that loss profit sharing is more stabil in both long and short terms, different from the system of interest which is very sensitive with change. 
In the theory of Islamic economics, the monetary policy is based on the real sectors (real sector oriented) with minimum role of money and money marke and on the other hand it holds the main role in running the economy. The monetary policy of Islam does not only intend to influence the money supply but also for making the credit fund run smoothly from the creditors to the debitors in the rule of shareea. The existence of financial intermediary foundation (bank and non bank) in the concept of Islamic economy is for supporting the performance of the real sectors and not for using the money in virtual business without lending the money in the form of loan to the real sectors.

The theory of Islamic monetary strictly forbids the use of interest as the instrument in the policy so that the equilibrium of supply and demand is given to the mechanism of market. When the economy is active, then the money offer from the creditors will be responded by the debitors with the return (profit and loss sharing) which is also high but when the economy is weak then the money offer from the creditors will not be fully responded by the debitors so that the return is also low. This mechanism will create a condition where the growth of fund correlates positively with the economics activities and needs. Besides that, this mechanism also deletes the excess liquidity caused by the growth of the fund which is not from the improvement of economic activities like what happens in Indonesia today.

The following is the opinion of Rifki Ismal (2014) about the new paradigm of monetary from the concept of Stiglitz which is actually the theory of Islamic economics:

\section{Money Doesn't Matter but Credit Matters}

Stiglitz found that the role of money in supporting the economic growth has been decreasing (money doesn't matter) and is replaced by the role of credit (credit matters). The policy of conventional monetary which so far uses the instrument of interest rate to influence money supply (monetary aggregate) is through a monetary mechanism. It is finally expected that it can positively affect the output (economic growth). According to Stiglitz it has to be changed into a policy which is based on the mechanism of demand and credit offer (real sector oriented). By so doing, the focus of new is the effort of providing credit in the economic system (not the arrangement of interest rate or money supply). So that it is expected that it can positively affect the economy.

In the theory of Islamic economics, monetary policy taken is oriented to the real sectors with minimum role of money and money market and on the other hand, it holds the main role which is running the economic system. Islamic monetary policy does not aim at influencing the amount of money supply but also making the flow of credit run smoothly from the creditors to the ebitors according to the Islamic law. The existence of financial intermediary foundation (bank and non bank) in the concept of Islamic economics is aimed at supporting the performance of the real sectors and not for using the money in the virtual world without distributing it in the form of loan to the real sectors.

\section{Causing the Risk of Imperfect Information}

Stiglitz sees the imperfect information in the credit market to cause banking hesitate to distribute credit and tends to avoid the risk (risk averse). Moreover in the credit from banks so that there is credit jam, has made banking industry thinks hard to give new loan to business runners. When there is loan, the fund is mostly used to invest (to take profit) from money market which promises big interest without doing anything. He thinks that bank should:

a. Not avoid the risk (risk averse) but being netral in distributing credits.

b. Not rely on the credit interest rate, and 
c. Distribute the risk effectively to all economic runners.

The unique thing is, what Stiglitz worried about are things that are concerned by the Islamic economics in banking so that is why Stiglitz's thought is considered the same as the principles of Islamic economics. In the theory of Islamic economis, especially in the concept of finance, there are some rules that need to be obeyed. They are:

a. Bank cannot guarantee the profit initially such as done by conventional banks from the interest of deposite which numbers have been determined at the beginning.

b. Bank cannot also put the risk only to one party (debitor) but also to the creditor/customer even the bank itself has the risk as it is seen in the concept of loss sharing where the money owner also gets the risk of what happens to their money.

c. The concept of finance in Islam is the activity of investing money (common business) not an investmen of only one side (risk free). So that there is no party that is free from the risk happens but together they take the responsibility of the profit or loss (the risk is distributed to the economic runners, exacty like what is uttered by Stiglitz).

\section{Interest Rate does not Have Central Role}

Stiglitz assumes that the adaptation of interest rate to make supply and demand in balance does not have central role anymore in today theory of monetary. The increase in monetary instrument done by the central bank still can be responded by the increase of interest rate in money market and credit interest rate so that it can lower the number of economic liquidity (economic expansion) and is expected to press te inflation. However, the decrease of interest rate which is the monetary instrument is not surely followed by the decrease of interest rate in money market, especially credit interest rate. Along with the more integrated money market, the money owners have many options to invest both in the country and abroad so that even though the interest rate decreases, the investors can still look for other revenue by putting their money in financial instrument in the country or abroad.

The theory of Islamic monetary strictly bans the use of interest instrument in its policy so thet the balance between money demand and supply is given to the market. When the economy is active, then the money offer by the creditors will be responded by the debitors and is followed by the return (profit and loss sharing) which is also high but when the economic condition is weak, the money offered by the creditors will not fully be responded by the debitors so that the return is also low. This mechanism will create a condition where the money growth positively relates with the activities and the needs of economy. Besides that, this mechanism can also delete the excess liquidity caused by the increase amount of money not from the increase of economic activities like what happens in Indonesia today.

From the above explanation, it is clear that the concept of Siglitz is almost similar with the concept of Islamic economics and can be described as follows:

Figure 3: Paradigm Monetary Policy

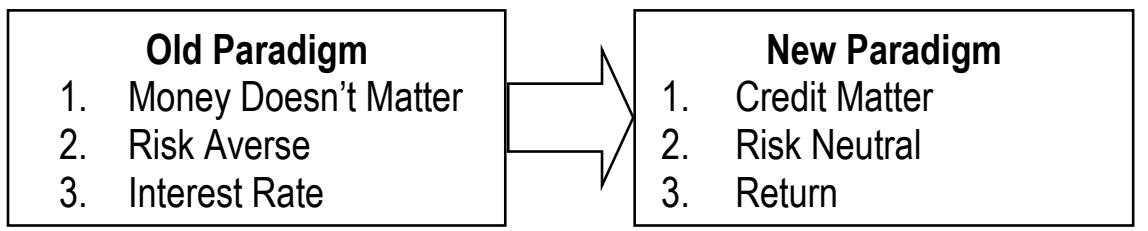

Source: Developed for this study (2017) 


\section{The Instrument of Islamic Monetary Policy}

The instrument of Islamic monetary policy can be done by the following steps:

\section{a. Statutory Reserve Requirement}

In islamic economics, this is the most important instrument, because the discount rate and the operation of an open market are not implemented. Bank is obliged to put part of its money from the demand deposit in the central bank as statutory reserve. This reserve requirement is only valid in demand deposit, not in mudarabah deposit.It is because mudarabah deposit is an equity of the customers in the bank where it is possible for them to get loss or profit. This system is good when it is supported by a good supervision from the bank itself (Muhamad, 2002).

\section{b. Credit Ceiling}

It is the highest limit that is given by the bank to guarantee that the total finance is in accordance with the monetary targets. By relying on reserve requirement that helps the central bank to adapt the high powered money, cannot guarantee the success of monetary policy because financial expansion can be implemented even more than what it is targeted. It is because the money flow that can be exactly measured can only be included in banking system from the mudarobah of the central bank with commercial bank. However the money flows from other sources which are included in the banking system are hard to determine accurately. The factor influencing it is because there is not clear relation between reserve requirement in the comercial bank with the expansion of finance. In short, what happens to money supply shows the interaction as internal factors and complex external factors, so that it is better when the credit ceiling is applied (Muhamad, 2002)

\section{c. Demand Deposit}

To influence reserves in the commercial bank, the government has the authority to move the demand deposit from the government in the central bank from and to the commercial bank. This instrument has a similar function with the operational function of open market, where the central bank directly influences the commercial bank (Siregar, 2000).

\section{d. Common Pool}

It is an instrument that requires commercial banks to spare part of the deposite in a particular proportion based on common agreement to overcome the problem of liquidity. This instrument has the similarity with the function of re-discount facility to the conventional central bank for solving problems related to liquidity (Siregar, 2000).

\section{e. Moral Suassion}

It is personal contacts, consultation, and meetings of the central bank with commercial banks to monitor the superiority and the problems faced by the commercial banks. With this instrument, the central bank can give correct and exact suggestion to solve the problems of banking, so that the purpose of banking that has been planned vcan be easily achieved (Siregar, 2000). 


\section{f. Equity-Base Instrument}

Equity-Base Instrument is an instrument with involvement. This instrument is suggested because of several reasons. First, the purchase and the sale of share of some public enterprises do not cause burden. Second, it does not need the security from the government. Third, the price variations of equity-base instrument published by the central bank in the operation of open market does not require profit or penalty from the share owners. Fourth, the posibility of the increase in share price bought by the central bank from the share owners can cause corruption, especially when they fundamentally do not agree.

\section{g. Treating the Created Money as Fay'}

It is the core money published by the central bank and it is one of the implementations of its prerogrative right. It brings benefit to the central bank because the expense used for making the money is lower than the value and it is known as money seignoraga. Because of the seignoraga, then it is reasonable if the central bank spares the fund into tax or fai', which mainly is used to fund the projects to improve the social economic condition of the society and can decrease the gap of people's income and wealth. The government cannot use this fund to pay the projects that can only benefit the rich people. With this instrument, the fund allocation can be accounted and distributed for people's beneficial activities.

\section{h. Goal Oriented Allocation of Credit}

The allocation of banking funding based on the aim of profit taking will give optimal benefit for all business runners and it will also produce goods and services that can be distributed to all layers of the society. In fact, it is really difficult to be true. It is because the fund gained by public banks mostly are from customers who have small amount of money, whereas the money is used to benefit those who have much bigger amount of money or the business runners. Banks usually hesitate to distribute the fund for small enterprises because they have bigger risks and usually they need bigger expenses. It makes the small enterprises find difficulty in getting finance from banks. When there is a bank which provides the finance, it must require many difficult conditions for the small enterprise runners, especially relates to guarantee. With this condition, it can be measured that the growth and the continuity of small enterprises is threatened, even though actually small enterprises can broaden work field, produce some goods, and improve the income distribution.

To overcome this problem, a guarantee scheme is needed for the bank to participate in financing productive enterprises which are not contradictive to the values of Islam. Through this guarantee scheme, bank does not have to ask for guarantee to the enterprises which propose to be financed. In this case, bank faces challenges of the financing done, which is when the enterprises financed gets failure in its business. When the failure is caused by morality, then the bank can get the money back. But if the failure is caused by the bad economic condition, then the bank also has to be responsible for the risk.

\section{The Transmission of Islamic Monetary Policy}

\section{a. Money Demand in Islam}

Money demand in Islam is a monetary management which is efficient and fair, not relying on the mechanism of banj rate, but using three main instruments as follows (Chapra, 1996): 
1) Value jugmement. It can create a condition which allows the allocation and distribution of fund sources which is in accordance with Islamic teaching. Basically, the resources are the gifts from Allah the All Mighty, and it has to be used efficiently and fairly. Based on the Islamic values, money demand has to be used to meet the basic needs and productive investment, not for conspicuous consumtion, non productive and speculative expenses. Money, like water, is a resource source belongs to the country. Therefore, money has to be used to improve the people's prosperity, not for enrich part of them. As a resource, money is harder to find than water. The management of money in the central bank is based on the finance of production and import. It is also based on the distribution of goods and services needed for meeting the needs of the people (Chapra, 1996). Basically, the human needs can be distinguished into two kinds, which are very important and less important (Karim, 2010). In this case, goods and services including the main needs have to be more prioritized than the secondary and tertiary needs. Also, the goods and needs of the majority have to be prioritized than those of the minority.

2) The foundations relate to social welfare, economy, and politics. This instrument includes the mechanism of pricing that can improve the efficiency in using the resource. The pricing mechanism is aimed at balancing the offer and demand of goods and service, so that it is in a just position among the economic runners. Pricing mechanism is not an activity that guarantees the achievement of economic goals of a country. Pricing mechanism which is according to Islamic rules will be a facility that can help to achieve the goals easily (Siregar, 2000).

3) Financial intermediation which is vased on profit and loss sharing. In this system, money demand is allocated only to beneficial projects and only to the debitors who can manage a project efficiently. With that condition, it is expected that money demand for paying useless, non productive and speculative projects can be reduced. Besides that, it can also create a society that has high enterpreunership even though they come from a poor society, however the rich people can also contribute. Finally the broadening of work field will be created and basic needs will be met (Siregar, 2000).

The above conditions are not only intended to the private sectors but also to the government. By so doing, financing will consider the appropriatness of the project and the ability of the government to manage the project. With this condition, the government will not get too much finance which is used for useless public facilities. In the short term, this condition can cause difficulties, but in the long term, it can create a better economy, as well as decrease the imbalance of budget and macro economiy.

Because the consumption of basic needs and productive investment tend to be more stabil compares to useless consumption and speculative investment, then the use of money demand for the previously mentioned need will be more stabil in Islamic economics.

Besides that, the profit- sharing ratio between the debitors and the finance will not fluctuate like interest rate. It is because the things are determined by the principle of justice, and once the ratio is determined, it will never change along the finance. By so doing, business will run based on the factors that do not have much change, so that the profit expectation will not extremely fluctuate. So, the financial intermedition which is based on equity sharing will tend to be more condusive in creating economic stability compared to financial intermedition which is based on loan. 
With various elements, islamic economic does not only minimize the unstability of the agregate but also influences many other components of money demand which in turn will improve the efficiency and the equity of money use. With the more stabil of money demand in islamic economic, then the stability will be created which is better for the velocity of circulation of money.

Money demand in islamic economic is shown in the following equation (Chapra, 1996):

$$
M d=f(Y s . S \cdot \pi)
$$

Notes:

Ys : Goods and services related to the meet of human basic needs and productive investment according to the Islamic values.

$S$ : The values of morality, social, and foundation (including zakah) which influence the allocation and distribution of resources which are not used for useless consumption, and speculative and non productive investment.

\section{$\pi \quad$ :Profit and loss sharing}

\section{b. The Actor of the Transmission of Monetary Policy}

The main actors of money market are the groups of creditors (the party offering money) and the group of debitors (those in need of money. But if we see it from the roles of making the money supply, there are three main actors in the money market. They are: monetary authority, financial foundation, and the society. In the Islamic system, the monetary foundation is the same as what exists today. But as a free interest system, Islam has different policy models. They are as follows (lqbal and Khan, 1981):

1) Monetary authorities (The central bank and the government)

The monetary authority has the main role as the first source which is the source of money supply. This group is the supply of money to meet the demand in the society and the money supply is needed by the foundations such as bank for the reserves. Money and bank reverse are the source or the seeds of the creation of money supply. Both of them are called as the core money or primary money.

Therefore, in the system of Islamic economics, the central bank as a trustworthy foundation managing the money supply will determine the annual program of money supply growth with the purpose of national economy. Operational system used in distributing money supply has to be interest free. One of the schema used is the central bank will open an account of imvestment in the banks which are the members as the deposite of mudarabah.

\section{2) Financial Foundation (Bank and Non Bank)}

Financial foundations are banks and other financial foundations such as investment foundation, insurance, and post office and giro. The main role of these foundations are as the source of money supply (DD), termed deposite (TD), saving (SD) and other financial actives acquired by the society. Monetary authority, together with other financial foundations, is what is called by monetary system. 
So, monetary system is the supplier of all people's need related to money; the monetary authority also provides primary money directly to the people, meanwhile the secondary money is provided by the financial foundation. This secondary money is created by banks and in accordance with the amount of primary money in the bank (Boediono, 1982). In Islamic system, of course it is not conventional bank, but financial foundations which are shareea based.

\section{3) Society (Household and Companies)}

The society is the end customer from the money created, where they use it to make the activities of production, consumption, and exchange run well.

\section{c. The Operation of Monetary Policy Transmission}

The approach of transmission used is actually almost similar to the one used by conventional banks but in Islamic rules, the monetary policy is clearly directed to the real sectors and the initial ideas uses the BI return. The transmission is aimed at the betterment of economic pattern.

The mechanism of BI Return can influence inflation is called as the mechanism of Islamic monetary policy tranmission. This mechanism draws the actions of Bank Indonesia trough changing monetray instruments and its operational targets so that it influences many economic variables and finance before finally it influences the end goal of inflation. The mechanism happens through the interaction among the central bank, banks, financial sectors and real sectors. The change of BI return influences many things such as the return, credit, exchange value, asset price, and expectation.

The following is the model of BI Return :

Figure 4: The Model of Islamic Monetary Policy (BI Return)

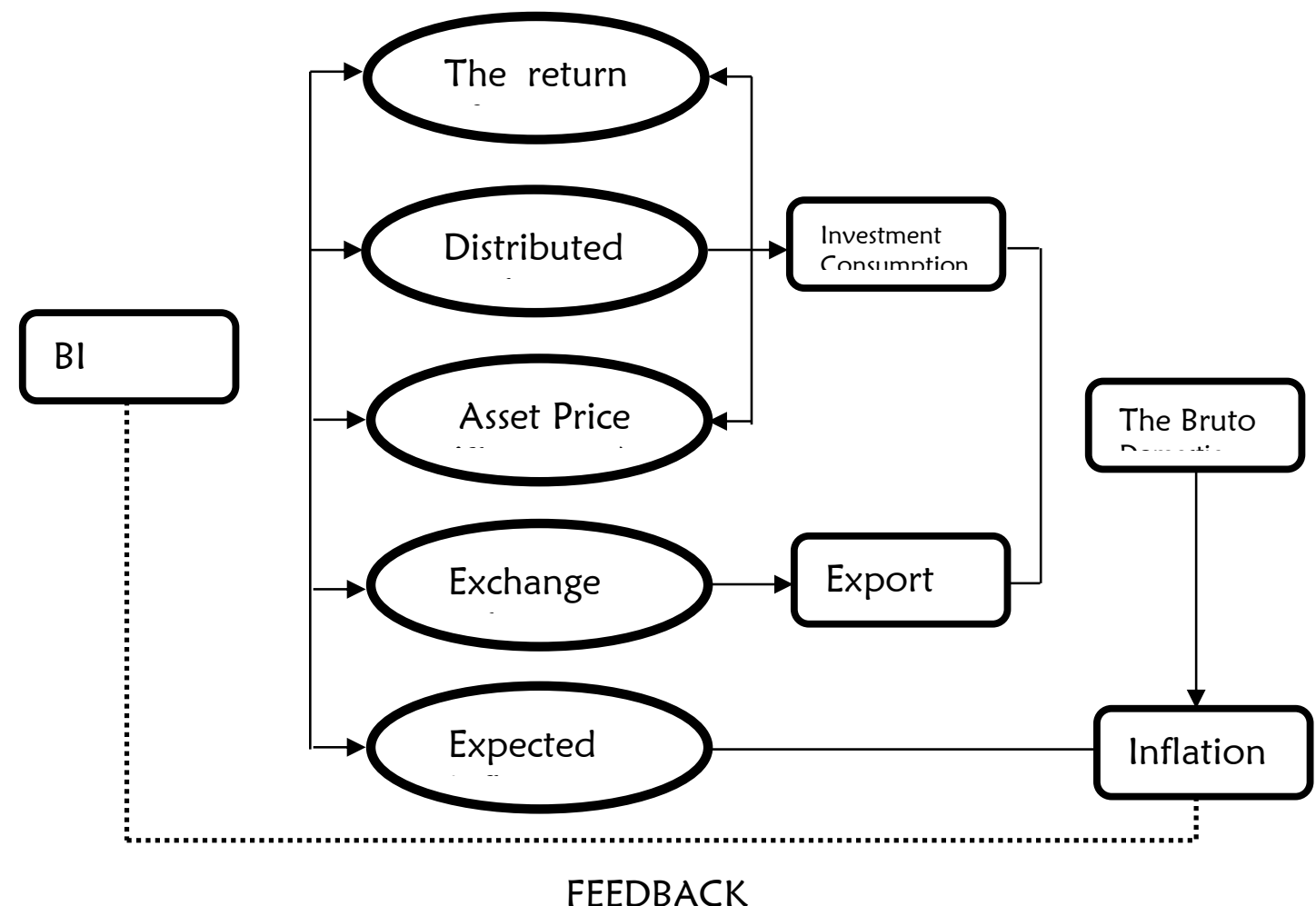

Souce: Developed for this study (2017) 


\section{CONCLUSION}

It can be inferred that today's monetary policy does not get along with the real sectors. Todays' world economy including in Indonesia is dominated by virtual transaction. The power of this money market is so strong compared to the power of the real market. Because of that, Islam bans strictly all virtual transactions without distributing it to the real sectors like what happens in the money market today.

As the solution to this problem, the government can implement the Islamic monetary policy that prioritizes the real sectors which is based on the $\mathrm{BI}$ return. It is in accordance with the monetary policy published by Rasulullah PBUH that was followed by the caliphates. It was always connected to the real sector which was trading. The result was the growth and stability.

Islam teaches an economic system which is right, fair, and humane for creating life prosperity. It is beneficial not only in the world but also in the hereafter. To achieve it, several efforts can be made through the instrument of monetary policy. Those efforts are: (1) Statutory Reserves Requirement, (2) Credit Ceiling, (3) Demand Deposit, (4) Common Pool, (5) Moral Suassion, (6) Equity Base Instrument, (7) Treating The Created Money as Fa'i, (8) Goal Oriented Allocation of Credit. 


\section{References}

Ahmad, Kurshid. (1992). Chapra. M. Umar. (2001). What is Islamic Economics, (Jeddah: IRTIB- IDB).

Arrieta, Gonzales. (1988). "Interest Rates, Saving and Growth in LDC: an Assesment of Recent Empirical Research". Word Development Report, vol 16.( New York: World Bank).

Bank Indonesia. (2004). Undang-undang Bank Indonesia Tentang Perubahan Atas Undang-undang Republik Indonesia Nomor 23 Tahun 1999 Tentang Bank Indonesia.

Boediono. (1982). Ekonomi Moneter, Seri Sinopsis Pengantar IImu Ekonomi No.2, Yogyakarta: BPFE.

Chapra, Muhammad Umer. (1996). "Monetary Management In an Islamic Economic". Islamic Economic Studies, vol. 4, No. 1, pp. 14-15.

Chowdury, Mas'udul Alam. (1997). Money in Islam. London: Routledge.

Iqbal, Munawar and Khan, M. Fahim. (1981). A Survey of Issues And Programme For Reseacrh In Monetary And Fiscal Economics of Islam, Jeddah: ICRIE King Abdul Aziz University.

Ismal, Rafiki. (2014). "Sistem Moneter dan Bank Islam". Materi Kuliah Program Doktor Ilmu Ekonomi Islam Universitas Airlangga.

Karim, Adiwarman Azwar. (2010). Ekonomi Makro Islam, Jakarta: PT Raja Grafindo Persada.

Khatkhate. (1988). "Assessing The Impact if Interest Rate Less Developing Countries". Word Development Report, vol 16 no 5 ( New York: World Bank).

Komaludin, Ade. (2009). Ekonomi Moneter, Teori dan Studi Empiris, Bandung: Rizqi Press.

Mannan, M. Abdul. (1986). Islamic Economics, Theory and Practice, Cambridge: Hodder and Stoughton, The Islamic Academy.

Muhammad. (2002). Kebijakan Fiskal dan Moneter dalam Islam. Jakarta: Salemba Empat.

Petticrew, M. and Roberts, H. (2006). Systematic Reviews in The Social Sciences. United Kingdom: Blackwell Publishing.

Siregar, Mulya. (2000). "Perlunya Manajemen Moneter yang Dapat Memperkecil Kegiatan Spekulasi". Analitica Islamica, Vol. 2, November.

Stiglitz, Joseph E. and Greenwald, Bruce. (2003). Towards a New Paradigm in Monetary Economics, Raffaele Mattioli Lecture, Cambridge.

Wahono, R. S. (2015). "A Systematic Literature Review of Software Defect Prediction: Research Trends, Datasets, Methods and Frameworks". Journal of Software Engineering Vol. 1, pp. 1-16.

Zaman, S. M Hasanuz. (1984). in Chapra, M. Umar (2001). What is Islamic Economics. (Jeddah: IRTI - IDB). 